\title{
NOTE
}

\section{Malignant lymphoma in black bullhead from Allouez Bay, Superior, Wisconsin, USA}

\author{
Vicki S. Blazer ${ }^{1}$, Candy S. Schrank ${ }^{2}$ \\ 'National Biological Service, Leelown Science Center, National Fish Health Research Laboratory, 1700 Leetown Road, Kearneysville, \\ West Virginia 25430, USA \\ ${ }^{2}$ Wisconsin Department of Natural Resourses, PO Box 7921, Madison, Wisconsin 53707, USA
}

\begin{abstract}
Leukemic malignant lymphoma was diagnosed in a black bullhead collected from Allouez Bay, in an industrialized Lake Superior estuary near Superior, Wisconsin, USA. No gross signs of thymic involvement were observed and it is believed this tumor originated in the hematopoetic tissue of the kidney. Neoplastic cells infiltrated excretory kidney, spleen, liver and gill tissue. This finding is of interest since occurrence of lymphoma has not previously been reported in this fish species. In addition, the general condition of black bullheads collected at this site was examined using a necropsy-based health assessment. Most parameters were within normal ranges. However, blood parameters and the amount of visceral fat suggested these fish may not be in optimal condition. Further work is needed to document the prevalence and cause of the neoplasm in this black bullhead population
\end{abstract}

KEY WORDS: Black bullheads - Malignant lymphoma Leukemia

Neoplasia of the lymphoid tissue of fish, particularly of species in the order Salmoniformes, are common (Dawe 1969, Fredrickson et al. in press). This is especially true in the northern pike Esox lucius and the muskellunge Esox masquinongy, in which the disease is believed to have a viral etiology (Papas et al. 1976, Sonstegard 1976). To our knowledge, hematopoetic neoplasms have only been reported twice in the order Siluriformes, both from channel catfish Ictalurus punctatus. These reports were of lymphoblastic lymphoma in captive channel catfish associated with longterm exposure to $\mathrm{N}$-methyl- $\mathrm{N}$ '-nitro- $\mathrm{N}$-nitrosoguanidine (Chen et al. 1985) and in an adult catfish from a commercial production pond in Mississippi, USA (Bowser et al. 1985).

A necropsy-based procedure (Goede \& Barton 1990, Goede 1993) for assessing the general health condition of fish is being tested as a systematic procedure for collecting information on the condition of feral populations. As part of testing the utility of this procedure selected tissues from black bullheads Ameiurus melas were preserved for histopathological evaluation. This communication reports a case of lymphoblastic lymphoma found as a result of conducting the general health assessment.

Methods. Fifteen black bullheads were collected on July 30, 1992, from a fyke net set for $24 \mathrm{~h}$ in Allouez Bay near Superior, Wisconsin, USA. Allouez Bay, approximately 1300 acres ( $320 \mathrm{ha}$ ) in size, is an extension of the Superior Bay and St. Louis River estuary system and is located at its southeastern end. General fish health was assessed using the procedure described in Goede (1993) with the following modifications: fat was ranked by rating the percent of intestinal surface covered; blood samples were taken from the branchial vein; the height of the buffy layer in the microhematocrit tube was measured in $\mathrm{mm}$ as a relative indicator of leucocrit. Blood smears were made from each fish, air-dried, fixed in methanol and stained with Leishman-Giemsa stain. Differential cell counts were made by examining 100 white blood cells located in random fields on each slide.

Visually obvious lesions or abnormalities were noted and selected samples of kidney ( $n=3$ fish), liver $(n=3)$, spleen ( $n=2)$, and gill $(n=4)$ tissue were preserved in Bouin's solution and transferred to $70 \%$ ethyl alcohol after 24 to $48 \mathrm{~h}$. The tissue samples were dehydrated, embedded in paraffin, sectioned at $6 \mu \mathrm{m}$ and stained with Harris's hematoxylin and eosin (H \& E) at the University of Wisconsin, School of Veterinary Medicine, Histology Laboratory.

Results. The 15 black bullheads collected from this site had a mean total length of $236 \pm 26$ (SD) mm. Mean weight was $186 \pm 69 \mathrm{~g}$. Mean age was $4.0 \pm 1.1 \mathrm{yr}$. One 
fish was $7+$ yr of age, all others were 3 to $4+$ yr of age. Of the 15 fish, 10 were female, 3 were male and 2 were undetermined. Condition factors [weight $(\mathrm{g}) \times$ $10^{5} /$ length $\left.^{3}(\mathrm{~mm})\right]$ averaged $1.4( \pm 0.1)$. Most of the fish had some degree of fraying of fins and parasites in the liver, and $47 \%$ had parasites in the kidney. All fish received normal ratings for the opercula, pseudobranch, thymus, spleen, and hind gut. One fish had an abnormal eye and $47 \%$ of the fish had clubbed, marginate or swollen gills. All fish had little fat with 0 to $<50 \%$ of intestine covered. Gall bladder appearance (full and yellow/green) indicated the fish had fed recently.

Hematocrits for fish $(n=14)$ other than the fish with the neoplasm averaged $30.5 \pm 6.4 \%$ packed red cells. Leucocrits averaged $1.3 \pm 0.6 \mathrm{~mm}$. Means ( \pm SD) for the differential counts $(n=11)$ made from the blood smears (not including the fish with the neoplasm) were as follows: $36.2 \pm 8.7 \%$ granulocytes (primarily neutrophils); $32.7 \pm 9.6 \%$ lymphocytes; $2.5 \pm 1.9 \%$ monocytes or blast cells; and $27.5 \pm 3.6 \%$ thrombocytes. The typical appearance of blood smears from fish without neoplasia is illustrated in Fig. 1.

The fish containing the neoplasm was female, $205 \mathrm{~mm}$ long, $122 \mathrm{~g}, 4+\mathrm{yr}$ of age and had a condition factor of 1.4 and grossly normal eyes, opercula, gills, pseudobranch, thymus, spleen and hind gut. The body cavity and liver contained parasites and the kidney appeared swollen. A number of the fins were frayed and/or hemorrhagic, with the caudal fin erosion rated as severe. Hemorrhages were present on the ventral body surface. The hematocrit was $18.8 \%$ and leukocrit $7.0 \mathrm{~mm}$. Differential counts were as follows: $4 \%$ granulocytes; $3 \%$ normal lymphocytes; $2 \%$ thrombocytes; and $91 \%$ neoplastic cells. Blood smears from this fish had a very different appearance (Fig. 2) when compared to those of the other bullheads. Neoplastic cells had a very basophilic cytoplasm and often had rounded cytoplasmic projections. The nuclei had a fine chromatin pattern and prominent nucleoli were often evident. Normal lymphocytes were 2 to $3 \mu \mathrm{m}$ smaller in diameter and had a lighter staining cytoplasm.

Pieces of spleen, liver, kidney and gill of the fish with the neoplasm were fixed during the field health assessment because of the abnormal appearance of liver and kidney. All of the above tissues contained neoplastic cells. These cells were fairly uniform in size, had large, round to oval nuclei with distinct membranes, prominent nucleoli and scattered chromatin granules. The cytoplasm was basophilic and apparent as an eccentric halo around the nucleus. Mitotic figures were common (Fig. 3).

In the gills, neoplastic lymphoid cells were present along the cartilage support of the filaments and filament vessels. Foci of neoplastic cells could also be found under the lamellar epithelium (Fig. 4). Branchial vessels were packed with neoplastic cells. Sections
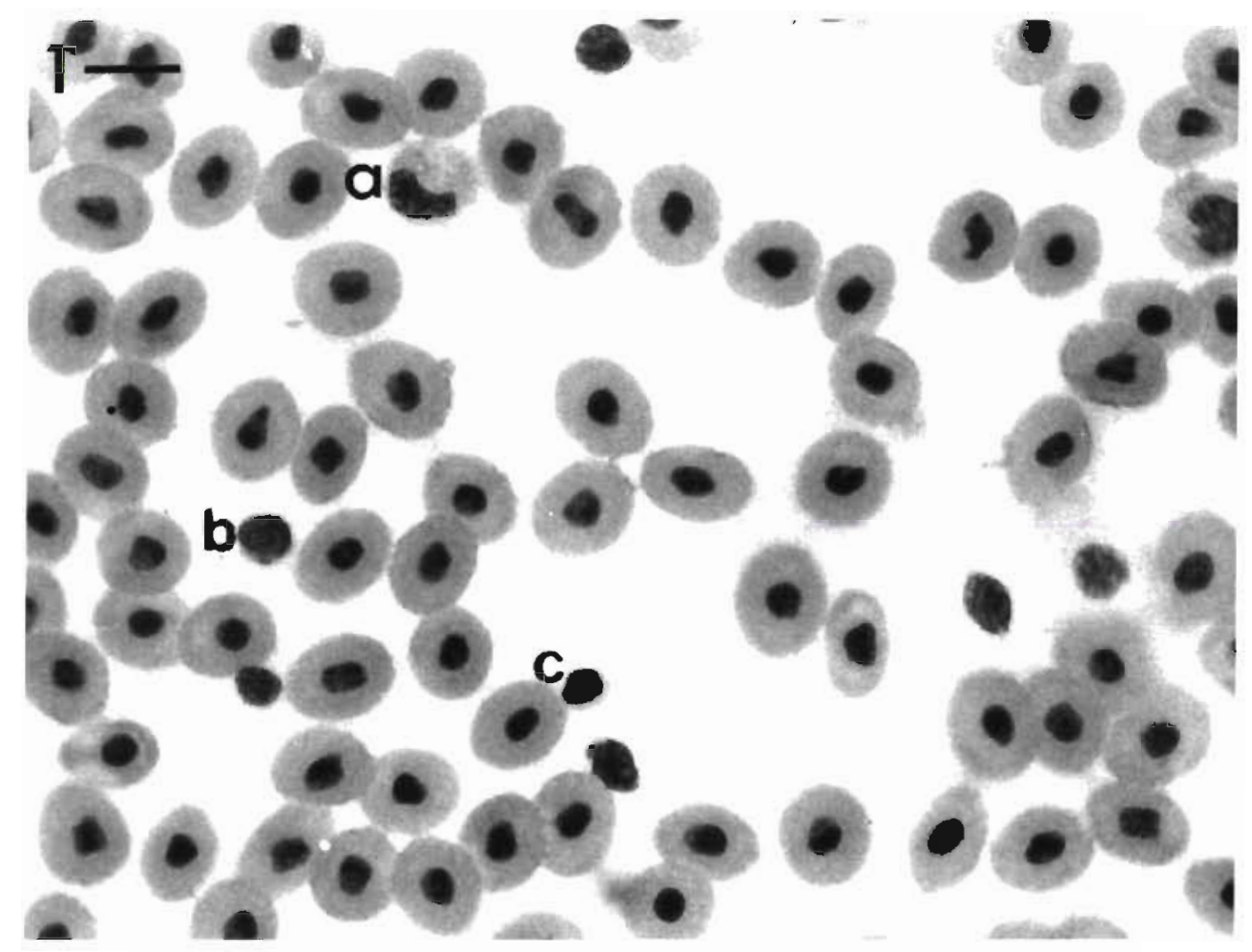

Fig. 1. Ameiurus melas. Blood smear of normal black bullhead collected in Allouez Bay, Superior, Wisconsin, USA, showing neutrophils (a), lymphocytes (b), thrombocytes (c) and red blood cells. Scale bar $=6.3 \mu \mathrm{m}$. Leishman-Geimsa stain 
Fig. 2. Ameiurus melas. Blood smear from a black bullhead with malignant lymphoma. The majority of white blood cells are neoplastic cells (arrows). A few normal neutrophils (a), thrombocytes and lymphocytes were observed. Scale bar $=6.3 \mu \mathrm{m}$. Leishman-Geimsa stain

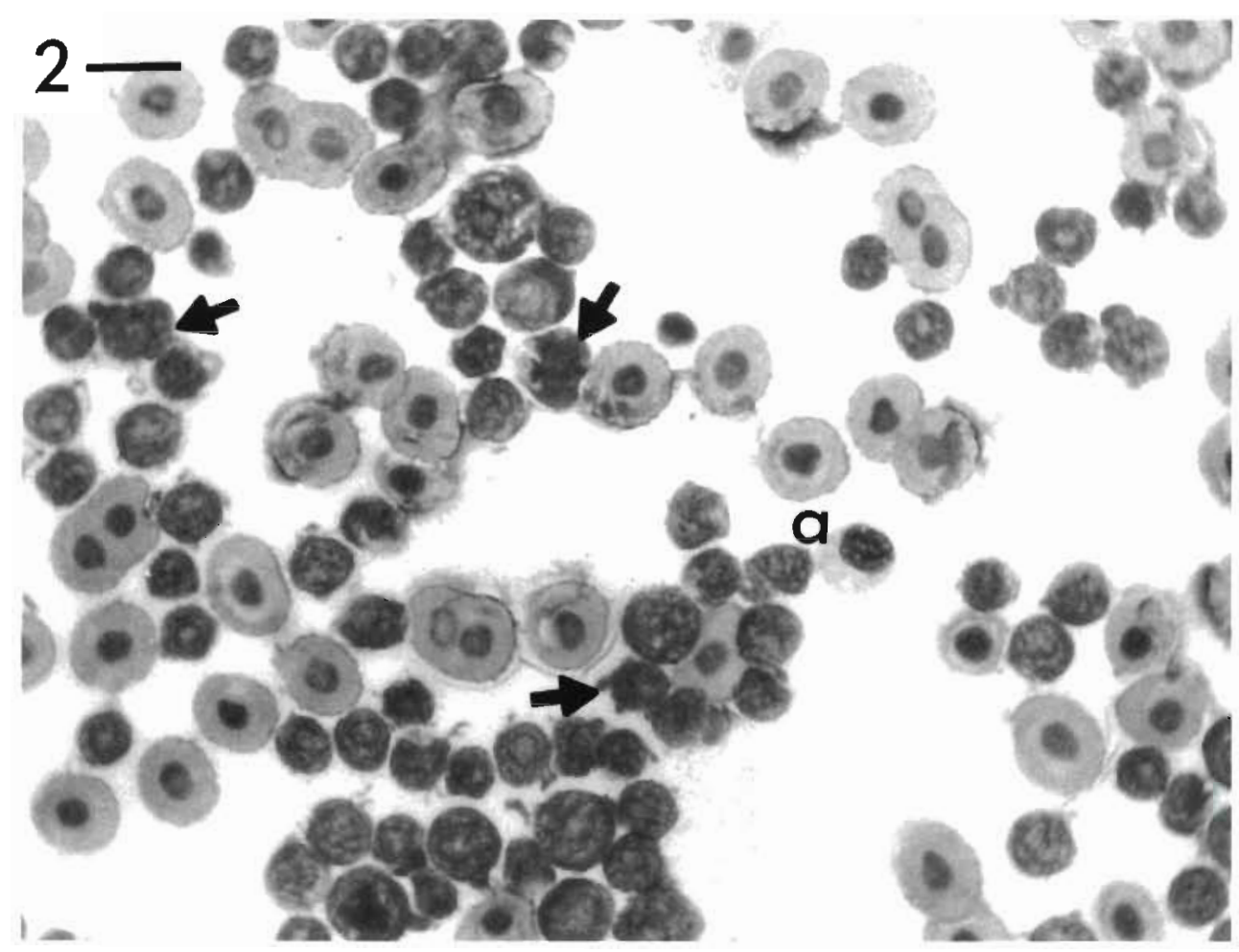

of the gill arch and pharynx showed neoplastic lymphoid cells infiltrating the muscle and dermis in these areas.

The liver was heavily infiltrated with neoplastic cells. Sinusoids were greatly distended by collections of these cells, which also filled the major vessels. There were focal areas of necrotic parenchyma within which neoplastic cells were seen. These cells invaded the bile duct epithelium but were not as common within pancreatic tissue (Fig. 5).
Fig. 3. Ameiurus melas. Neoplastic lymphoid cells in hematopoetic kidney tissue of a black bullhead. These cells are fairly uniform in size, have a large nucleus with prominent nucleolus and scattered chromatin granules, and a small rim of pale cytoplasm. Mitotic figures (arrows) were common. Scale bar $=16 \mu \mathrm{m}$. H \& E

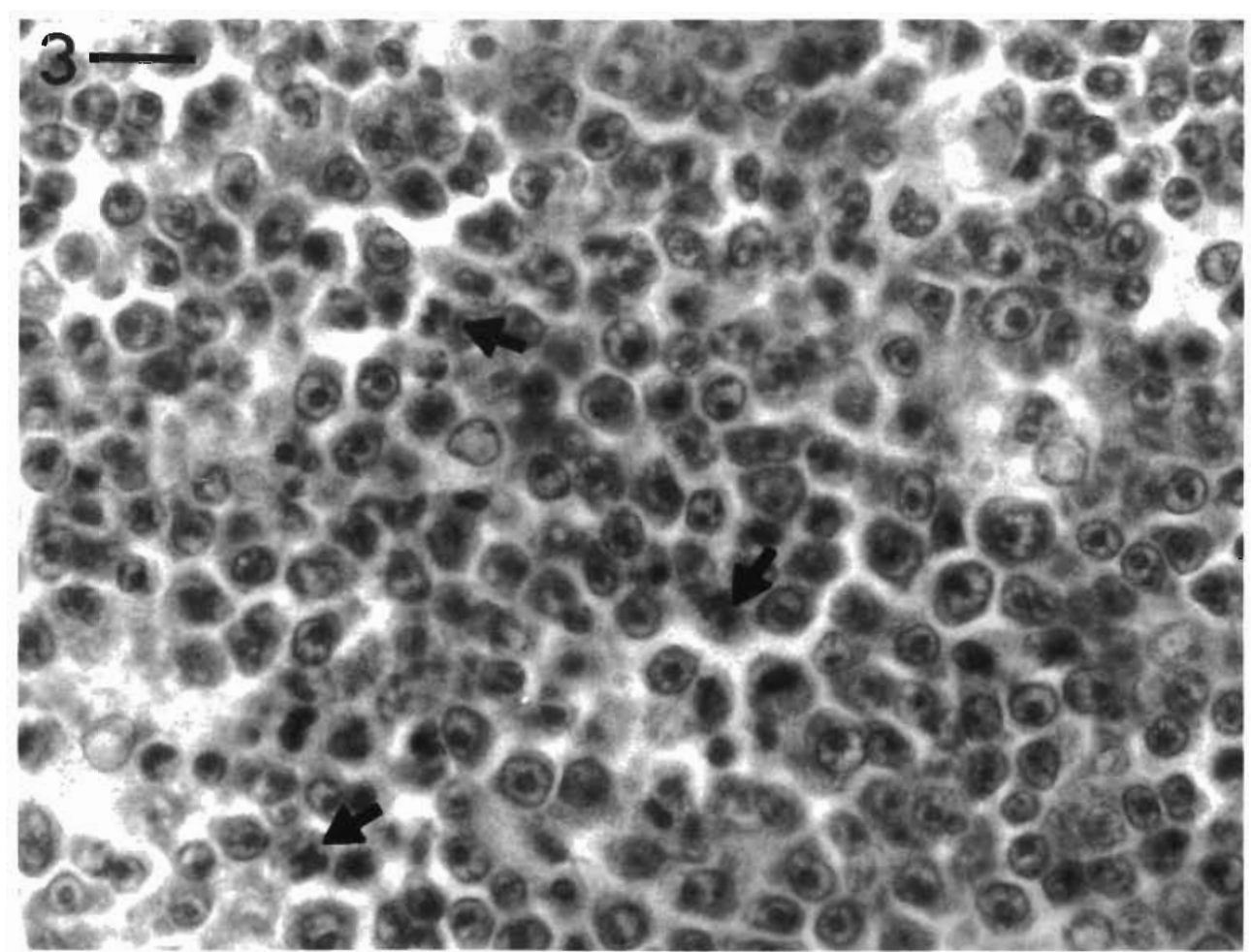




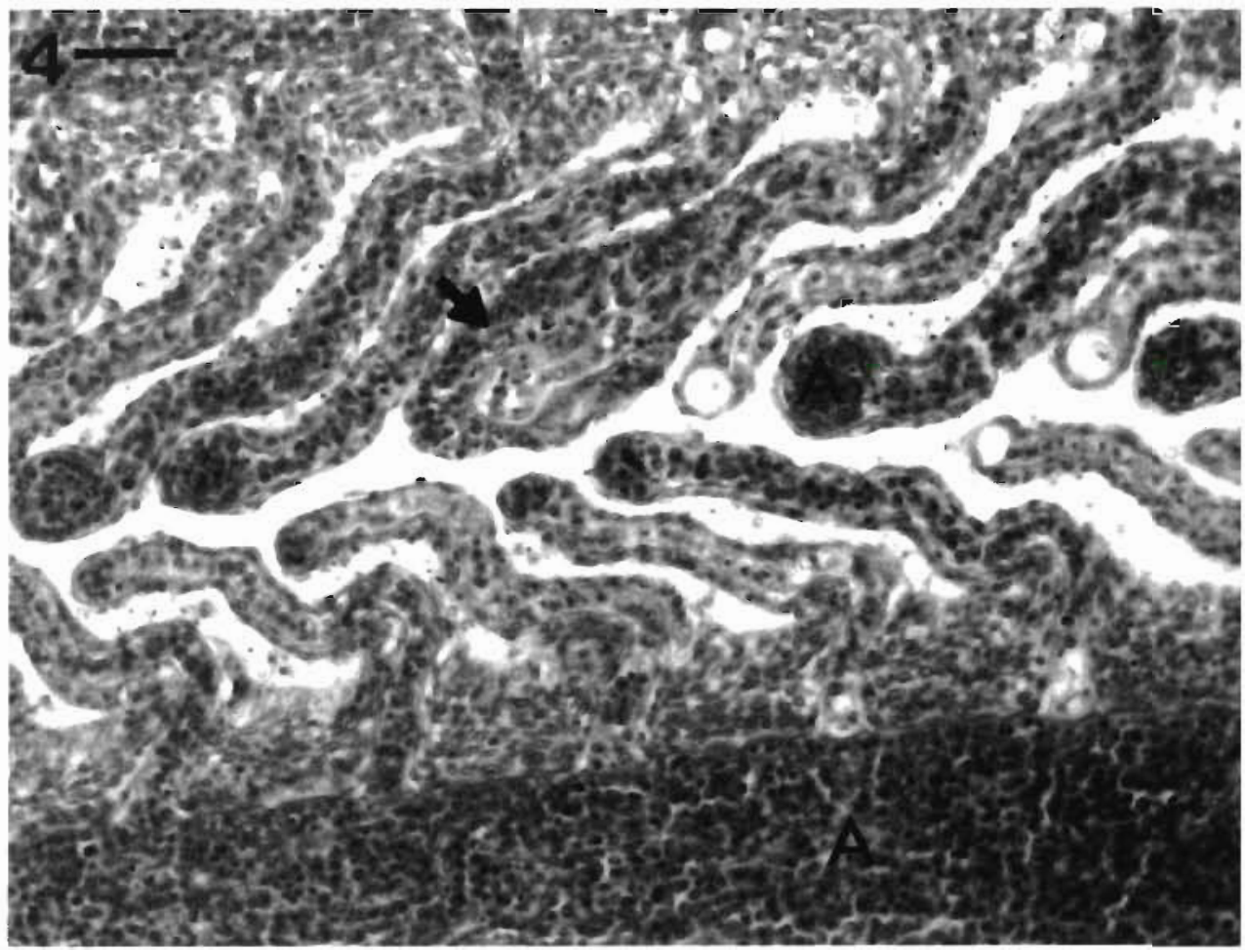

Fig. 4. Ameiurus melas. Gill filament of black bullhead with malignant lymphoma Branchial vessels (A) are filled with neoplastic cells These cells can also be seen outside of the vessels, under the lamellar epithelium (arrows). Scale bar $=63.5 \mu \mathrm{m}$ $H \& E$

Hematopoetic tissue of both the spleen and kidney had the typical 'starry sky' appearance at low magnification. These large, foamy macrophages often contained necrotic debris. Neoplastic cells filled the interstitium of the posterior kidney, markedly separating the tubules. These cells also packed the glomerular tuft, causing distention. In addition, neoplastic cells invaded the tubular epithelium (Fig. 6) and appeared, in some cases, to replace the tubules.

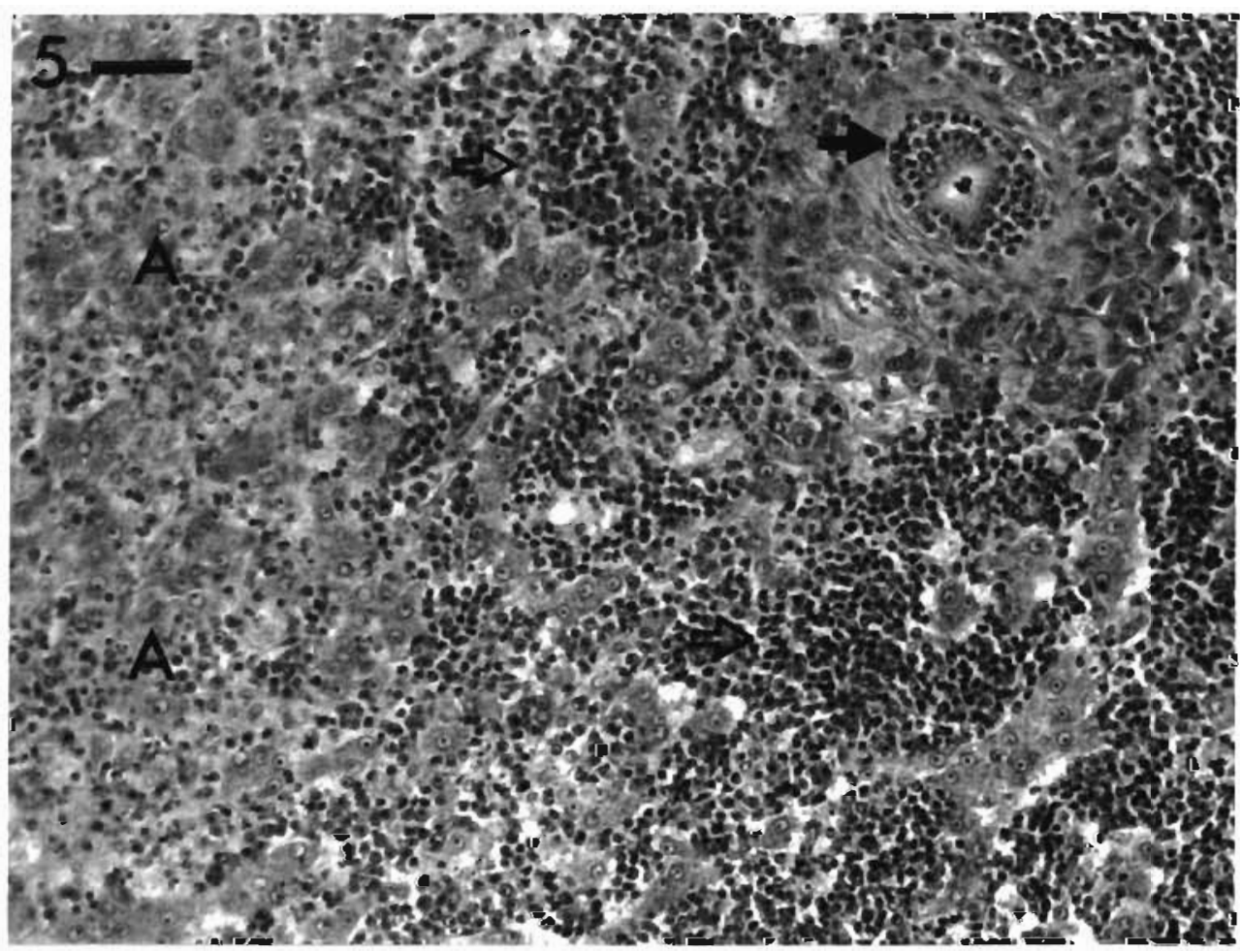

Fig. 5. Ameiurus melas Liver of black bullhead with malignant lymphoma. The sinusoids are distended by collections of neoplastic cells (open arrows), which were also observed in areas of necrotic parencyma (A) and invading the bile duct epithelium (closed arrows). Scale bar $=63.5 \mu \mathrm{m} . \mathrm{H} \& \mathrm{E}$ 
Fig. 6. Ameiurus melas. Kidney of a black bullhead with malignant lymphoma. Neoplastic cells are abundant in the interstitial tissue, within renal vessels (A) and were also observed infiltrating the tubular epithelium (closed arrows). Debris-laden macrophages (open arrows) were present. Scale bar $=50 \mu \mathrm{m}$. $\mathrm{H} \& \mathrm{E}$

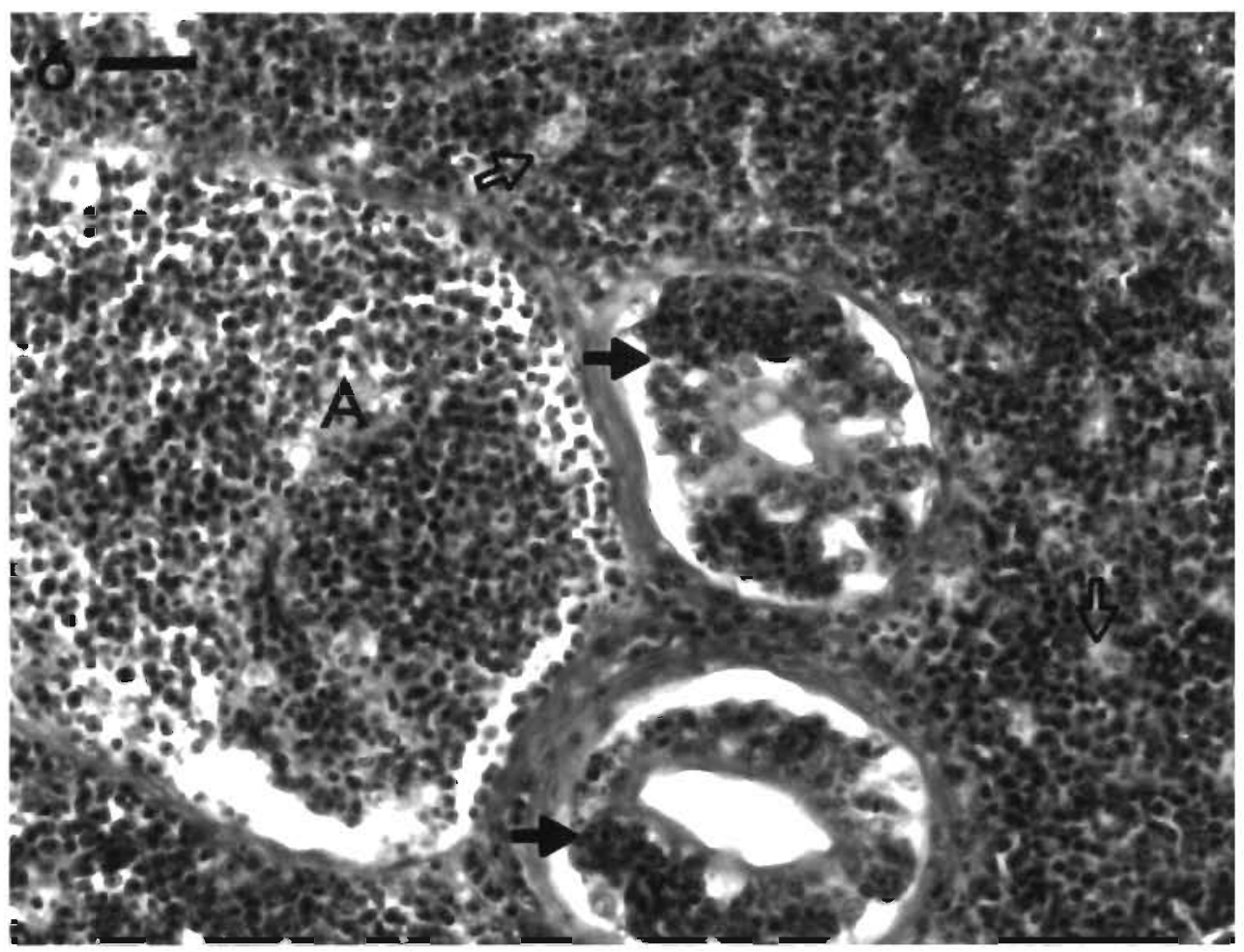

Discussion. Lymphomas are the most commonly reported hematopoetic neoplasms of fish. The reports are primarily of members of the Esocidae (pike and muskellunge) and Salmonidae (trout and salmon). They most often originate in the thymus in salmonids and in the skin in esocids (Fredrickson et al. in press). There is evidence that the esocid tumors are viralinduced (Mulcahy \& O'Leary 1970, Papas et al. 1976), as is plasmacytoid leukemia of netpen-raised salmon (Eaton \& Kent 1992). Recent evidence, based on electron microscopy and immunological markers, suggests that the pike tumors are not lymphomas but that the cell of origin is of the monocyte lineage and hence the tumors may be histiocytomas (Thompson \& Kostiala 1990). There are other arguments for the cell of origin to be Langerhans cells (Fredrickson et al. in press). Immunohistochemical characterization of pike tumors from the Baltic coast of Estonia suggests there are actually 3 tumor types: histiocytic, histiocytoid-lymphocytic and lymphocytic (Bogovski et al. 1994).

There are a few reports in which the neoplastic cells are believed to originate in the pronephros (Williams 1931, Haddow \& Blake 1933, Bowser et al. 1985, Hoffmann et al. 1988). In a number of these cases nodular swelling of the kidney was reported. In channel catfish (Bowser et al. 1985), as in the black bullhead, the kidneys were enlarged but not nodular.

Although a viral etiology is suspected for a number of the hematopoetic tumors of fish, there are a few reports of chemically-induced lymphosarcomas
(Schwab et al. 1978, Schultz \& Schultz 1984, Chen et al. 1985). In addition, a correlation between the frequency of lymphoma in pike and environmental contamination has been reported (Brown et al. 1973).

It is interesting to speculate on a chemical etiology for the lymphoma in black bullhead. Superior Bay and the St. Louis River estuary areas have a long history of industrial and commercial use and sediments have elevated levels of metals and organic pollutants (Janisch 1992). Sediment concentrations of polycyclic aromatic hydrocarbons at some locations exceed levels found at other sites in the Great Lakes where liver neoplasms have been diagnosed in fish (Baumann et al. 1991). In addition, a complex mixture of petroleum manufacturing by-product spilled from a derailed tankcar into the Nemajdi River on June 30, 1992, approximately 19 miles upstream of where the river enters Superior Bay, and resulted in a fish kill (Caldwell 1993).

The 15 black bullheads collected from Allouez Bay were within ranges of values reported in the literature for length, weight, and condition factors (Carlander 1969, Becker 1983). However, the blood parameters and small amount of visceral fat suggest that the health of all bullheads collected at this site may have been impaired or that the fish were stressed. Further work is needed to determine if our observations are a result of capture methods, exposure to environmental stressors prior to capture, or species differences.

In conclusion, we believe this to be the first report of malignant lymphoma in bullheads. It occurred in an 
adult female, was leukemic based on evaluation of blood smears, and may have been chemically induced. Further work should be conducted in this area to determine the prevalence of the neoplasia, normal hematology of black bullheads and possible long-term effects of the spill and in situ sediment contaminants on the hematopoetic tissue of fish in this area.

Acknowledgements. We thank Dr John Harshbarger, Registry of Tumors in Lower Animals, Smithsonian Institute, Washington, D.C., for verifying the diagnosis of this tumor. A slide from this study was catalogued in the Registry's collection as RTLA no. 5975. Assistance by Dennis Pratt and Sue Marquenski of the Wisconsin Department of Natural Resources is also appreciated. We are also indebted to John Fournie, Environmental Protection Agency, Gulf Breeze, for a critical review of the manuscrupt.

\section{LITERATURE CITED}

Baumann PC, Mac MJ, Smith SB, Harshbarger JC (1991) Tumor frequencies in walleye and brown bullhead and sediment contaminants in tributaries of the Great Lakes. Can J Fish Aquat Sci 48:1804-1810

Becker GC (1983) Fishes of Wisconsin. University of Wisconsin Press, Madison

Bogovski S, Rossi L, Bocchini V, Lastrioli S, Aiello C, Santi L (1994) Immunohistochemical characterization of malignant lymphoma in northern pike, Esox lucius L., from Estonian Baltic waters. J Fish Dis 17:557-566

Bowser PR, McCoy CP, MacMillan JR (1985) A lymphoproliferative disorder in a channel catfish, Ictalurus punctatus (Rafinesque). J Fish Dis 8:465-469

Brown ER, Hazdra JJ, Keith L, Greensberg S, Kwapinski JBG, Beamer P (1973) Frequency of fish tumors in a polluted watershed as compared to nonpolluted Canadian waters Cancer Res 33:189-198

Caldwell CA (1993) Hematopathological and histopathological responses in fish from the Nemadji River following the June 30, 1992 chemical spill. In: Documentation of natural resource injury resulting from the June 30, 1992 Nemadji River spill. U.S. Fish and Wildlife Service, National Fisheries Contaminant Research Center, La Crosse, WI, p 1-25

Carlander KD (1969) Handbook of freshwater fishery biology. Vol 1. Lowa State University, Ames

Chen HHC, Brittelli MR, Muska CF (1985) Two cases of lymphosarcoma in channel catfish exposed to N-methyl-N'nitro-N-nitrosoquanidine. J natl Cancer Inst 74:933-939

Responsible Subject Editor: N. Peters, Hamburg, Germany
Dawe CJ (1969) Neoplasms of blood cell origin in poikilothermic animals: a review. Natl Cancer Inst Monogr 32:7-28

Eaton WD, Kent ML (1992) A retrovirus in chinook salmon (Oncorhynchus tshawytscha) with plasmacytoid leukemia and evidence for the etiology. Cancer Res 52:6496-6500

Fredrickson TN, Walsh AH, Wolke RE (in press) Neoplasms of lymphoid and other hemopoetic tissues. In: Dawe $C_{\text {. }}$ Harshbarger JC, Wellings SR, Strandburg J (eds) Pathobiology of spontaneous and induced neoplasms in fishes: morphology, comparative characterization and literature. Academic Press, New York

Goede RW (1993) Fish health/condition assessment procedures. Part 1. Utah Division of Wildlife Resources, Fisheries Experimental Station, Logan

Goede RW, Barton BA (1990) Organismic indices and an autopsy-based assessment as indicators of health and condition of fish. In: Adams SM (ed) Biological indicators of stress in fish. Am Fish Soc Symp 8. American Fisheries Society, Bethesda, MD, p 93-108

Haddow A, Blake I (1933) Neoplasia in fish: a report of six cases with a summary of the literature. J Pathol Bacteriol 36:41-47

Hoffmann RW, Fischer-Scherl T, Pfeil-Putzien C (1988) Lymphosarcoma in a wild grayling. Thymallus thymallus L.: a case report. J Fish Dis 11:267-270

Janisch T (1992) The St. Louis River System remedial action plan. Stage one. Appendix D. Sediment quality assessment for the St. Louis River area of concern. Wisconsin Department of Natural Resources, Bureau of Water Resources Management, Madison

Mulcahy MF, O'Leary A (1970) Cell-free transmission of lymphosarcoma in northern pike, Esox lucius L. (Pisces, Esocidae). Experientia 26:891

Papas TS, Dalberg JE, Sonstegard RA (1976) Type C virus in lymphosarcoma in northern pike (Esox lucius). Nature 261:506-508

Schultz RJ, Schultz ME (1984) Characteristics of a fish colony of Poeciliopsis and its use in carcinogenicity studies with 7,12-dimethylbenz(a)-anthracene and diethylnitrosamine. Natl Cancer Inst Monogr 65:5-13

Schwab M, Haas J, Abdo S, Ahuja M, Kollinger G. Anders A, Anders $F(1978)$ Genetic basis of susceptibility for development of neoplasm following treatment with $n$-methyln-nitrourea (mnv) or x-rays in the platyfish/swordtail system. Experientia 34:780-782

Sonstegard RA (1976) Studies on the etiology and epizootiology of lymphosarcoma in Esox (Esox lucius L. and Esox masquinongy). Prog exp Tumor Res 20:141-155

Thompson JS, Kostiala AAI (1990) Immunological and ultrastructural characterization of true histiocytic lymphoma in the northern pike, Esox lucius L. Cancer Res (suppl) 50: $5668-5670$

Williams G (1931) On various fish tumors. Proc Trans Liverpool biol Soc 45:98-109

Manuscript first received: March 10, 1995

Revised version accepted: July 17, 1995 